\title{
Phagomyxa bellerocheae sp. nov. and Phagomyxa odontellae sp. nov., Plasmodiophoromycetes feeding on marine diatoms
}

Received: 30 July 2000 / Received in revised form: 25 September 2000 / Accepted: 5 October 2000 / Published online: 15 November 2000 (C) Springer-Verlag and AWI 2000

\begin{abstract}
The parasitic Plasmodiophoromycetes Phagomyxa bellerocheae sp. nov. and P. odontellae sp. nov. have been found in the North Frisian Wadden Sea; North Sea, feeding on the centric diatoms Bellerochea malleus and Odontella sinensis, respectively. Their structure and development is investigated by light microscopy and compared. The diagnoses are given. The life cycle of P. odontellae takes about a week.
\end{abstract}

Keywords Phagomyxa bellerocheae P Phagomyxa odontellae Bellerochea malleus . Odontella sinensis . Plasmodiophoromycetes

\section{Introduction}

In September 1993, a Phagomyxa algarum-like organism infecting the centric diatom Bellerochea malleus (Brightwell) van Heurck was detected in plankton samples collected in the Wadden Sea off List/Sylt (North Sea, German Bight) (Schnepf 1994). P. algarum was described by Karling (1944) as a parasite of the filamentous brown algae Ectocarpus mitchellae Harv. and Pylaiella fulvescens (Schousb.) Bornet in North Carolina. He discussed whether $P$. algarum belongs to the Plasmodiophoromycetes or the Proteomyxetes. Most of his data suggested that Phagomyxa be placed in the Plasmodiophoromycetes despite phagocytozing food particles and

Communicated by K. Lüning

S.F. Kühn (

Meeresbotanik (FB2), Universität Bremen,

Leobener Strasse/NW2, 28334 Bremen, Germany

e-mail: skuehn@uni-bremen.de

Tel.: +49-421-2182582, Fax: +49-421-2182285

E. Schnepf

Zellenlehre, Fakultät für Biologie, Universität Heidelberg,

Im Neuenheimer Feld 230, 69120 Heidelberg, Germany

S. Bulman

New Zealand Institute for Crop and Food Research,

Private Bag 4704, Christchurch, New Zealand digesting them in a specialized vacuole, in contrast with other members of the taxon. Our studies on the fine structure of plasmodia and zoospores of a $P$. algarumlike parasite of $B$. malleus indicate that it is undoubtedly a plasmodiophoromycote (Schnepf 1994).

In September 1995, in plankton samples from the same site, we observed a similar but obviously not identical Phagomyxa species feeding on the diatom Odontella sinensis (Schnepf 1999). Here we compare the two organisms using light microscopy. We conclude that they are two different species, and present the diagnoses. They are named Phagomyxa bellerocheae Schnepf sp. nov. and Phagomyxa odontellae Kühn, Schnepf \& Bulman sp. nov., respectively.

\section{Materials and methods}

Two Phagomyxa species were detected in plankton samples routinely collected in the North Frisian Wadden Sea off List/Sylt. They were investigated using light microscopy mainly on live specimens, with Leitz seawater immersion objectives. We tried to cultivate the parasites with their hosts in Petri dishes supplied with $\mathrm{F} / 2$ medium (Guillard and Ryther 1962 ) at $15^{\circ} \mathrm{C}$.

\section{Results}

Phagomyxa bellerocheae

Specimens of $P$. bellerocheae were detected in September 1993 parasitizing the chain-forming diatom Bellerochea malleus (Brightwell) van Heurck and then observed regularly in the following years in autumn and early winter. Occasionally, when B. malleus was very abundant, up to $90 \%$ of the cells in a chain were infected (Fig. 1). Since only $B$. malleus was parasitized, $P$. bellerocheae seems to be strictly host-specific.

Attempts to cultivate $P$. bellerocheae have not yet been successful. Therefore the complete life cycle is still to be observed and the generation time cannot be determined. $P$. bellerocheae first becomes visible as a hyaline 

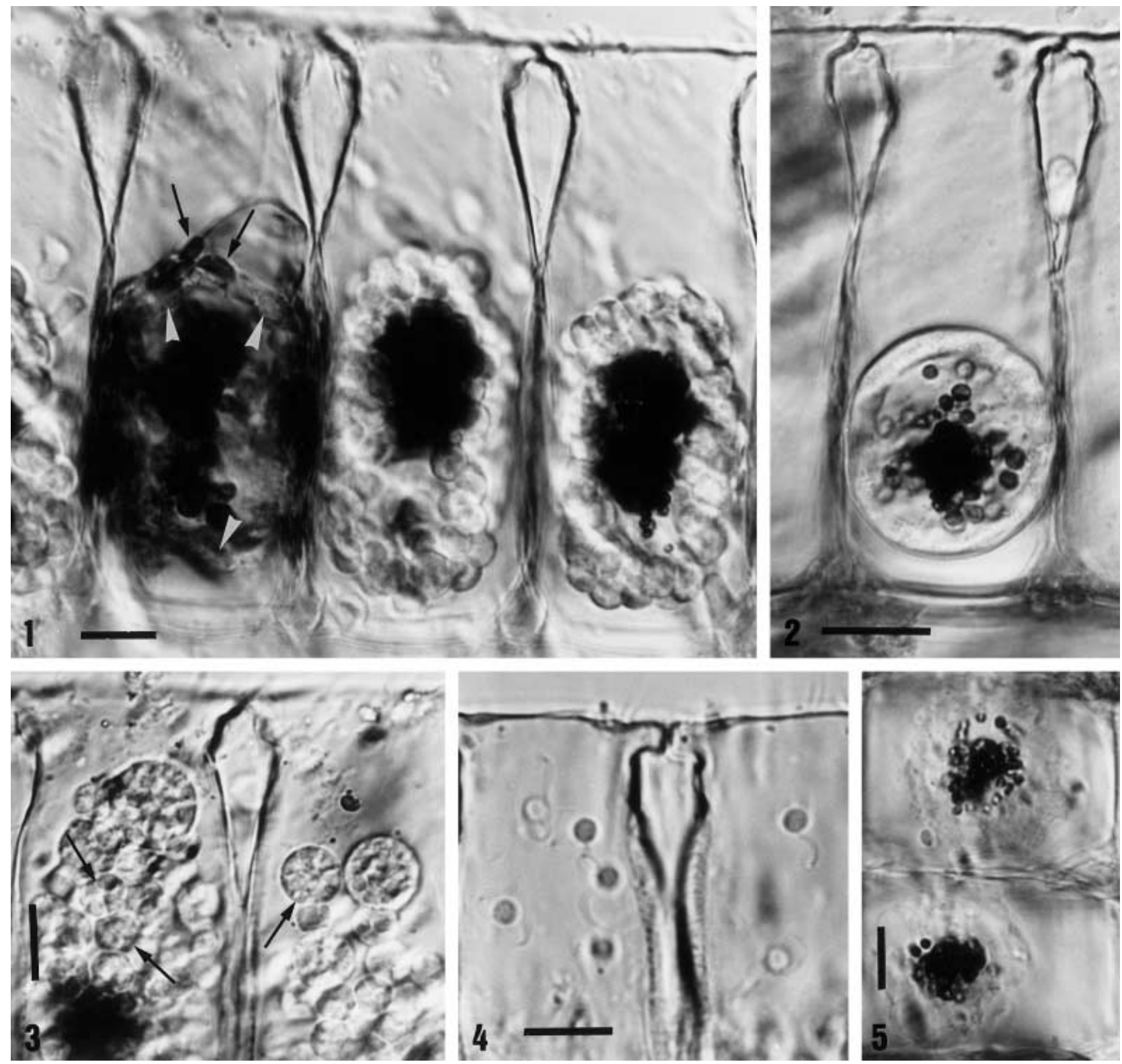

Fig. 1 Phagomyxa bellerocheae parasitizing Bellerochea malleus. Young plasmodium (arrowheads) within a plasmolyzed host protoplast with non-phagozytized chloroplasts (arrows) in the left host cell. The middle and the right cells each contain a sporangiosorus with many zoosporangia surrounding a residual body of undigested host cytoplasm. Living material, bright field. Scale bars $20 \mu \mathrm{m}$

Fig. 2 Phagomyxa bellerocheae parasitizing Bellerochea malleus. Plasmodium before cleaving, with a central digestion vacuole. Living material, bright field. Scale bars $20 \mu \mathrm{m}$

Fig. 3 Phagomyxa bellerocheae parasitizing Bellerochea malleus. Zoosporangia of different sizes, some are cleaving (arrows). Living material, bright field. Scale bars $20 \mu \mathrm{m}$

Fig. 4 Phagomyxa bellerocheae parasitizing Bellerochea malleus. Newly released zoospores within a Bellerochea cell. Living material, bright field. Scale bars $20 \mu \mathrm{m}$

Fig. 5 Phagomyxa bellerocheae parasitizing Bellerochea malleus. Two host cells with empty zoosporangia and a central residual body. Living material, bright field. Scale bars $20 \mu \mathrm{m}$ plasmodium within the already plasmolyzed host cytoplasm (Fig. 1). The plasmodium becomes the shape of an oval to spherical hollow sphere (Fig. 2). A single, large central digestion vacuole is filled by phagocytosis with an increasing amount of host cytoplasm, especially chloroplasts. The details of the feeding process cannot be observed clearly. Eventually the plasmodium consists of indistinctly separated portions. It remains enveloped by the host plasma membrane until it cleaves into a sporangiosorus, a loose group of dozens of zoosporangia which surround a dark-brown residual body (Figs. 1, 3).

Each zoosporangium is globular to polygonal, has a thin wall, and measures $4-10 \mu \mathrm{m}$ in diameter. The contents of the zoosporangia cleave into zoospores (Fig. 3). The number of the zoospores depends on the size of the zoosporangium.

The zoospores are initially irregular in shape, later becoming pyriform, $2.5 \mu \mathrm{m}$ in diameter and $4 \mu \mathrm{m}$ in length, 
with two subapically inserted flagella (Fig. 4). The forward directed flagellum is $4 \mu \mathrm{m}$ long, the backward trailing one $8 \mu \mathrm{m}$ long. Electron microscopy revealed that flagellar hairs are absent (Schnepf 1994). When the zoospores leave the zoosporangium, faint remnants of the sporangial walls and a dark-brown residual body remain (Fig. 5). Further developmental stages have not been observed.

\section{Phagomyxa bellerocheae Schnepf sp. nov}

\section{Description}

Plasmodium unum, parasiticum in diatomis marinis, ovalium vel globosum, 25-30 $\mu \mathrm{m}$ latum, 30-40 $\mu \mathrm{m}$ longum maturitate, circumdantium res cibarias et accumulatium eaedem in vacuolo magno singulari mediano. Sporangiosorus unus, ovalius vel globosus, cyvus, 20-25 $\mu$ m latus $\times 30-35 \mu \mathrm{m}$ longus. Zoosporangia frequentia, hyalina, sphaerica vel angularia, 4-10 $\mu \mathrm{m}$, sine papilla ostelaribus. Zoospores pyriformes, $2.5 \times 4 \mu \mathrm{m}$, cum flagellis levibus. Flagellum ad anteriorem versum $4 \mu \mathrm{m}$, flagellum ad posterorem versum $8 \mu \mathrm{m}$.

\section{Diagnosis}

Single plasmodium, parasitizing marine diatoms, oval to spherical, 25-30 $\mu \mathrm{m}$ wide and 30-40 $\mu \mathrm{m}$ long when fully grown, with a single, large digestion vacuole in which undigested host material is accumulated. A single, hollow sporangiosorus, oval to spherical, 20-25 $\mu \mathrm{m}$ wide and 30-35 $\mu \mathrm{m}$ long. Numerous hyaline zoosporangia, spherical or polyhedral, surrounded by a delicate wall without exit papilla. Zoospores pyriform, $2.5 \times 4 \mu \mathrm{m}$, with two apically inserted, smooth flagella. The forward directed flagellum $4 \mu \mathrm{m}$ long, the backward directed, trailing one $8 \mu \mathrm{m}$ long.

Type locality: North Frisian Wadden Sea off List/Sylt, parasitizing Bellerochea malleus.

Type micrograph: Fig. 1.

Synonyms: Phagomyxa-like endosymbiont of B. malleus (Schnepf 1994, Figs. 1-24), Phagomyxa sp. (Elbrächter and Schnepf 1998, Figs. 28-31).

\section{Phagomyxa odontellae}

Examples of $P$. odontellae were first detected in September 1995 in plankton samples from the North Frisian Wadden Sea off List/Sylt, parasitizing the diatom Odontella sinensis (Greville) Grunow. It was occasionally also found in autumn of the following years, but was more abundant again in September/October 1998 and in September 1999.

Until now it has only been cultivated for 2 or 3 weeks, together with its host, $O$. sinensis. Neither $B$. malleus (the host of P. bellerocheae) nor Ectocarpus sp. (a putative host of $P$. algarum; Karling 1944) were accepted as food.

The very first stages of the infection could not be observed. The plasmodium is hyaline and initially hardly visible within the host cytoplasm. It is indirectly recognized by clusters of aggregated chloroplasts and lipid droplets of the host (Fig. 6). Strands of host cytoplasm run through the central vacuole of an infected Odontella cell whereas the cytoplasm of uninfected cells has an exclusively peripheral position.

Later developmental stages are characterized by many small food vacuoles with dark-brown contents. The plasmodium becomes net-like with the food vacuoles in the corners of the meshes (Fig. 7). Eventually the food vacuoles fuse and the plasmodium partitions into several sporangiosori, each surrounding one or two dark-brown residual bodies. The sporangiosori are preferentially but not exclusively situated in the four corners of the host cell (Fig. 8) and consist of many (up to more than 100) globular zoospores with a diameter of 4-7 $\mu \mathrm{m}$ (Fig. 9).

The cytoplasm of the zoosporangia cleaves to form zoospores. They are pyriform to kidney-shaped, 3-4 $\mu \mathrm{m}$ long and $2-3 \mu \mathrm{m}$ in diameter (Fig. 10). The two flagella are laterally inserted. The long trailing flagellum is about $10 \mu \mathrm{m}$ long, the shorter, apically directed one $8 \mu \mathrm{m}$ long. After their release the zoospores remain immobile for some time within the diatom cell. The development from infection to zoospore liberation takes about 1 week under laboratory conditions $\left(15^{\circ} \mathrm{C}\right)$

Phagomyxa odontellae Kühn, Schnepf \& Bulman sp. nov

\section{Description}

Plasmodium unum, parasiticum in diatomis marinis, reticulatum, maturitate in totis regionis cellulae, circumdantium res cibarias et accumulandum easdem in multis vacuolis parvis. Sporangiosori plures. Zoosporangia eorum numerosa, circumdantia residua cibi non digesta. Zoosporangium globosum, 4-7 $\mu \mathrm{m}$, sine papillis ostelaribus. Zoospores pyriformes vel reniformes, $3-4 \times 2-3 \mu \mathrm{m}$, cum flagellis lateri insertis. Flagellum ad anteriorem versum $8 \mu \mathrm{m}$, flagellum ad posteriorem versum $10 \mu \mathrm{m}$.

\section{Diagnosis}

Single plasmodium, parasitizing marine diatoms, reticulate when fully grown and filling the peripheral parts of the host cell, with numerous small digestion vacuoles. Several sporangiosori, the zoosporangia of which surround one or two residual bodies. Zoosporangia spherical, 4-7 $\mu \mathrm{m}$ in diameter, without discharge papilla. Zoospores pyriform to kidney shaped, $3-4 \times 2-3 \mu \mathrm{m}$. Flagella laterally inserted, the forward directed flagellum $8 \mu \mathrm{m}$, the backward directed, trailing one $10 \mu \mathrm{m}$ long. 

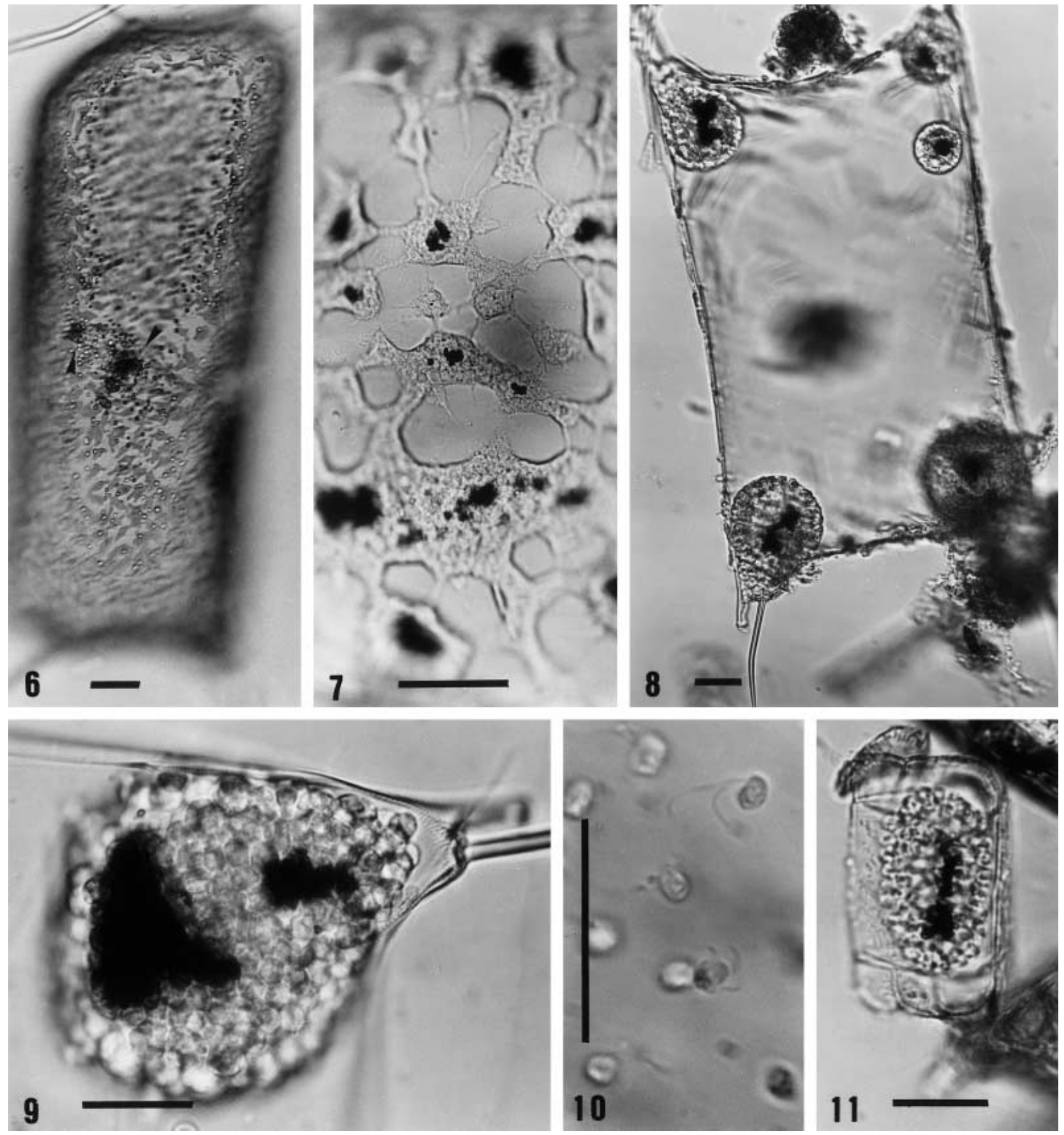

Fig. 6 Phagomyxa odontellae, parasitizing Odontella sinensis. Newly infected cell. Chloroplasts and lipid bodies accumulating (arrow heads) around a small Phagomyxa plasmodium which is not directly visible. Living material, bright field. Scale bar $20 \mu \mathrm{m}$

Fig. 7 Phagomyxa odontellae, parasitizing Odontella sinensis. Fully grown net-like plasmodium with many digestion vacuoles filled with not yet fully digested host cytoplasm. Living material, bright field. Scale bar $20 \mu \mathrm{m}$

Fig. 8 Phagomyxa odontellae, parasitizing Odontella sinensis. Host cell with several sporangiosori each including one or two residual bodies. Living material, bright field. Scale bar $20 \mu \mathrm{m}$

Fig. 9 Phagomyxa odontellae, parasitizing Odontella sinensis. Sporangiosorus with many zoosporangia and two residual bodies. Living material, bright field. Scale bar $20 \mu \mathrm{m}$

Fig. 10 Phagomyxa odontellae, parasitizing Odontella sinensis. Newly released zoospores within an Odontella cell. Living material, bright field. Scale bar $20 \mu \mathrm{m}$

Fig. 11 Phagomyxa odontellae, parasitizing Odontella sinensis. A sporangiosorus with residual body of a not yet identified Phagomyxa in a Biddulphia alternans cell. Living material, bright field. Scale bar $100 \mu \mathrm{m}$ 
Type locality: North Frisian Wadden Sea off List/Sylt, parasitizing $O$. sinensis.

Type micrograph: Fig. 8.

Further observations

In September 1994 a Phagomyxa-like organism was detected in Chaetoceros sp. (Kühn 1995) and in September 1999 a similar one in Biddulphia alternans (Bailey) Van Heurck (Fig. 11). It remains uncertain whether they are identical with one of the other Phagomyxa species.

\section{Discussion}

The question of whether Phagomyxa is a member of the Plasmodiophoromycetes has been discussed by Karling (1944). Electron microscopy investigations of P. bellerocheae by Schnepf (1994) confirmed this assumption. On the few occasions when $P$. odontellae has been successfully cultivated for a short time, it has been found that the zoospores directly infect new host cells and that cysts and cystosori, found in other Plasmodiophoromycetes, are not formed in Phagomyxa. Phagocytosis, which is not observed in other Plasmodiophoromycetes, is also a unique feature of Phagomyxa. Molecular biological analyses have been initiated to determine the exact position of Phagomyxa within the Plasmodiophoromycetes.

The two new species, P. bellerocheae and P. odontellae, are similar in some respects, e.g. the general features of development, phagocytosis, structure and size of the sporangiosori, zoosporangia and zoospores. They differ, however, in several details:

1. Shape of the plasmodium. P. bellerocheae forms a hollow sphere, $P$. odontellae a three-dimensional net.

2. Position of the plasmodium within the host cell. Retracted in $P$. bellerocheae, peripheral in $P$. odontellae.

3. Number of food vacuoles. A single, large, central food vacuole in $P$. bellerocheae, numerous small food vacuoles in the corners of the net meshes in P. odontellae.

4. Number of sporangiosori formed from a plasmodium. Only one in P. bellerocheae, several in P. odontellae.
5. Length of the flagella of the zoospores. They are $4 \mu \mathrm{m}$ and $8 \mu \mathrm{m}$ long in P. bellerocheae but $8 \mu \mathrm{m}$ and $10 \mu \mathrm{m}$ in $P$. odontellae.

Obviously the two organisms are not host races but belong to different species. Molecular biological analyses should confirm this.

Difficulties in cultivation has not allowed us to determine the host range of the species. This is unfortunate because $O$. sinensis is not an indigenous alga but was introduced from East Asia and first found in the North Sea in 1903 (Drebes 1974). It is, therefore, not clear whether P. odontellae also has indigenous hosts (as e.g. Biddulphia alternans, Fig. 11), whether it has evolved from an indigenous species, or whether it has been introduced. The fact that $P$. bellerocheae and $P$. odontellae have been detected only recently is of little significance. Many protists feeding on algae have been overlooked and have only recently been detected (e.g. Kühn 1995; Kühn et al. 1996; Elbrächter and Schnepf 1998).

Acknowledgements Most of the investigations have been done in the Alfred-Wegener-Institute for Polar and Marine Research, Wattenmeerstation List/Sylt. We thank Dr. G. Drebes for his hospitality and Ms H. Halliger for technical assistance. We thank E. Hummel for correcting the Latin diagnoses.

\section{References}

Drebes G (1974) Marine phytoplankton. Thieme, Stuttgart

Elbrächter M, Schnepf E (1998) Parasites of harmful algae. In: Anderson DM, Cembella AO, Hallegraeff GM (eds) Physiological ecology of harmful algal blooms. (NATO ASI series, vol G 41) Springer, Berlin Heidelberg New York, pp 351-369

Guillard RRL, Ryther JH (1962) Studies on marine phytoplankton diatoms. 1. Cyclotella nana Hustedt and Detonula confervacea (Cleve) Gran. Can J Microbiol 8:229-239

Karling JS (1944) Phagomyxa algarum n. gen. n. sp., an unusual parasite with plasmodiophoralean and proteomyxean characteristics. Am J Bot 31:38-52

Kühn S (1995) Untersuchungen zum Befall von Phytoplankton durch parasitoide Protisten (Nordsee). Dissertation, University of Bremen

Kühn SF, Drebes G, Schnepf E (1996) Five new species of the nanoflagellate Pirsonia in the German Bight, North Sea, feeding on planktic diatoms. Helgol Meeresunters 50:205-222

Schnepf E (1994) A Phagomyxa-like endoparasite of centric marine diatom Bellerochea malleus: a plasmodiophoromycete. Bot Acta 107:374-382

Schnepf E (1999) Beobachtungen an Protisten, die sich von Algen ernähren. V. Teil: Amöben und plasmodiale Protisten. Mikrokosmos 88:305-312 